\title{
ANALYSIS OF PASSENGER SATISFACTION OF SERVICES IN TERMINAL 3 ULTIMATE SOEKARNO-HATTA INTERNATIONAL AIRPORT
}

\author{
Rida Aulia Wulansari ${ }^{1}$, Syafira Tria Permata ${ }^{2}$ \\ 1. STMT Trisakti, 2. STMT Trisakti \\ corresponding author: ridaaulia17@gmail.com
}

\begin{abstract}
Airport Terminal is a facility where passenger movement is in in-bound and out-bound process on air transport. The airport terminal is divided into 2 sections, namely Passenger Terminal and Cargo Terminal. This paper aims to explain and predict the satisfaction of passengers on service at Terminal 3 Ultimate Soekarno-Hatta International Airport. In this study the method used was the Likert scale method, which evaluated the passenger's perception of airport terminal service on international departures. Data collection was taken from a sample of 70 people. Based on the results of this study, the quality of service consisting of information service boarding signage, Security Check Point, Check-in Counter, Immigration and Boarding Lounge passenger are satisfying with the overall percentage of $76.4 \%$.
\end{abstract}

Keywords-: Airport Terminal, Passenger Satisfaction, Passenger Terminal, Airport Services, Airport.

\section{Introduction}

The growth of air transport implies an increasing demand for airport services, which then evolves into the need to provide more effective and efficient airport terminal services (Manataki \& Zografos, 2009). Along with the increasing growth in the number of passenger traffic flow, then PT Angkasa Pura II (Persero) Soekarno-Hatta International Airport is always trying to fix the service, because they are required to always show the performance and quality of performance as possible for the satisfaction of the passengers (Agushinta \& Wiratama, n.d.). PT Angkasa Pura II (Persero) is one of the State-Owned Enterprises engaged in airport services and airport-related services in the area of West Indonesia. Angkasa Pura II has gained the trust of the Government of the Republic of Indonesia to manage and strive for the operation of Cengkareng Airport Jakarta which has now been renamed to Soekarno-Hatta International Airport since August 13th, 
1984. Now, Angkasa Pura II has managed 13 airports, one of them is Soekarno-Hatta International Airport.

Soekarno-Hatta International Airport is the largest airport in Indonesia, the airport is located in Cengkareng, West Jakarta but geographically located in District Benda, Tangerang City with an area of 1740 Ha. Based on the Minister of Transportation Decree no. 11 of 2010 on the Order of the National Airport, Soekarno-Hatta International Airport is categorized as a collector airport with a primary care scale of greater or greater amount equivalent to 5,000,000 (five million) people per year, making this airport the busiest airport in Indonesia with an average passenger growth of $19.2 \%$. To overcome this growth, Soekarno-Hatta Airport is developed to accommodate passengers about 62 million passengers per year, one solution with the construction of Terminal 3 Ultimate which is planned to accommodate the capacity of movement of 25 million passengers (Pradana \& Ahyudanari, 2017). The terminal for passenger is one of the most important parts of the airport that has served as a venue for all passenger activities from the beginning of departure until arrival. Before flying, passengers must pass through 4 different processes: security check point, check-in counter, immigration and boarding lounge (Kalakou \& Moura, 2015). In practice the use of the terminal area is as a mean of transit (Nurtjahjo, Rianto; SE, 2016). Facility component at Terminal 3 Ultimate which we will analyze is passenger satisfaction of service at Terminal Departure Terminal 3 Ultimate. Quality of service is the level of good condition of the poor offer of facilities provided by the international airport terminal Soekarno-hatta in order to satisfy the passengers (Pengguna et al., 2016). Terminal 3 Ultimate is a terminal that will serve international flights at Soekarno-Hatta Airport which is ready to improve the performance of international aviation terminal, and it is expected Terminal 3 Ultimate will reduce the overload or over-capacity problem that happens in terminal 2 at this time. Flight frequency is increasing and terminal 3 ultimate is expected to carry passengers up to less 
than 25 million passengers per year (Suhaedi \& Ariyanto, n.d.). Adequate facilities will affect the quality of passenger services, by seeing the satisfaction of passengers at Soekarno-Hatta Airport with the existence of terminal 3 ultimate international airport soekarno-hatta, research conducted in 2017 was implemented to analyze the quality of service, consisting of the accuracy of boarding signage, service level in immigration gate, comfort in boarding lounge, conformity of standard operation on security check point, and check-in counter to passenger satisfaction at the airport terminal (Sastranegara, n.d.). The existence of related conditions of infrastructure and operations in passenger satisfaction needs to be undertaken to evaluate existing facilities, operating systems implemented as well as procedures in serving passengers. From these problems, the important thing is to know the passenger satisfaction of the service in terminal 3 ultimate and the frequency of passengers coming to terminal 3 ultimate.

As described above, the analysis of passenger satisfaction for service at the Soekarno-Hatta International Airport terminal has several issues that must be addressed. The formulations of the problem is:

How is the service (including boarding signage, security check point, checkin counter, immigration, and boarding lounge) in Terminal 3 Ultimate?

The benefit gained from this analysis is expected to be able to know passenger satisfaction at Terminal 3 Ultimate Soekarno-Hatta International Airport.

\section{Method}

This research type used Quantitative Research Method. Research methods Quantitative is a research method based on the philosophy of positivism, used to examine in certain samples, data collection using research instruments, data analysis is quantitative / statistical, with the aim to test the hypothesis that has been established (Sugiyono, 2011: 8). In the methodology, measurement of every variable in this research had used ordinal scale and instrument scale used in this research was using Likert Scale with range 1-5. We had taken a random sample of 70 respondents at 
Terminal 3 Ultimate Soekarno-Hatta International Airport by spreading the questionnaire through google form based on the services in Terminal 3 Ultimate Soekarno-Hatta International Airport such as Boarding Signage, Security Check Point, Check-in Counter, Immigration, and Boarding Lounge.

The data collection in this research came from primary data. Primary data obtained from the respondents were people who responded or answered the statement through the questionnaire. Data collection techniques used in this study was Field Study, namely by spreading the questionnaire (questionnaire).

\section{Discussion and Result}

\section{A. Analysis of Accuracy on Boarding Signage}

It can be seen from Figure 1 that overall perception of boarding signage accuracy is $70.9 \%$. This shows that the most respondents state that they have been accurate and in accordance with the information posted on boarding signage.

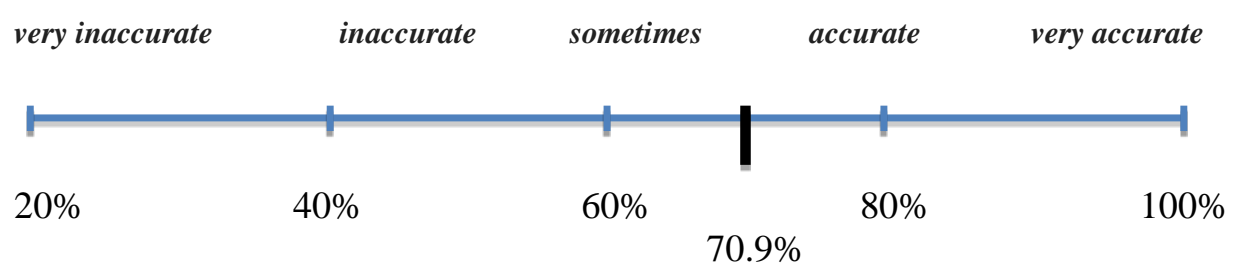

Figure 1 Continuum Line Response Response Against Boarding Signage Accuracy

B. Service Analysis on Security Check Point

Based on Figure 2 it can be seen that the overall perception of the suitability of the standard security check point is $79.14 \%$. This shows that the most respondents state that the security check point in terminal 3 ultimate is in accordance with the applicable standard that is 3 minutes when passengers pass the security check point. 


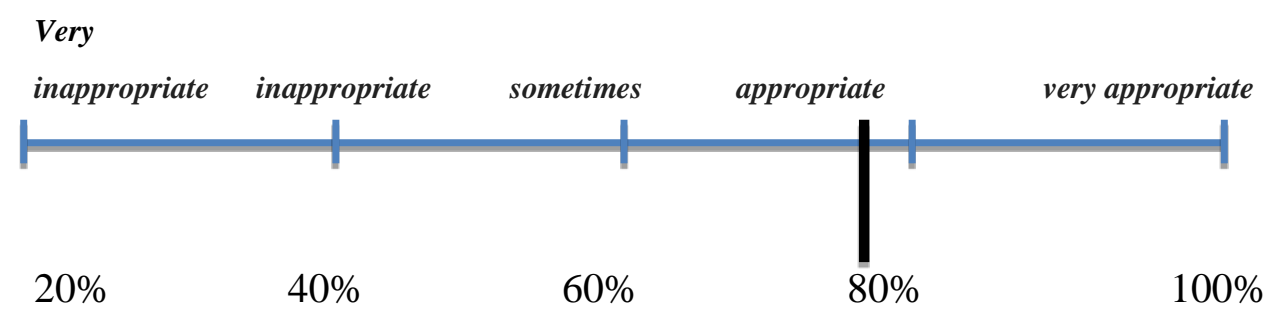

$79.14 \%$

Figure 2 Continuum Line Response Respondents Against Security Check Point Services

C. Service Analysis on Check-In Counter

Based on Figure 3 it can be seen that overall perception of standard conformity at check in counter is $77,4 \%$. This shows that the most respondents state that the check-in counter service is in compliance with the applicable standards, the officer checks the travel documents and weighs the baggage of the passengers.

Very

inappropriate inappropriate sometimes appropriate very

appropriate

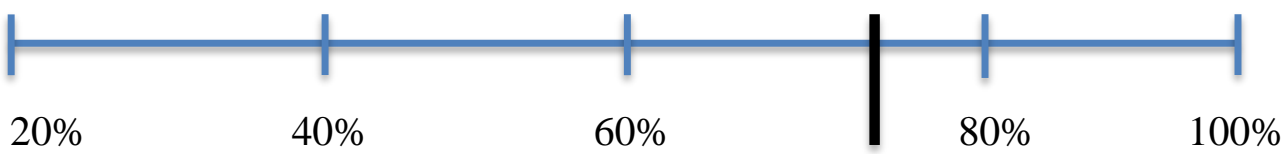

$77.4 \%$

Figure 3 Line Continuum Respondents Response Against Check-in Counter Service

D. Service Analysis on Immigration Gate

Based on Figure 4, it can be seen that overall perception of document examination service in immigration gate is good with percentage $78 \%$. This shows that the most respondents state that the document examination service in immigration gate is good.

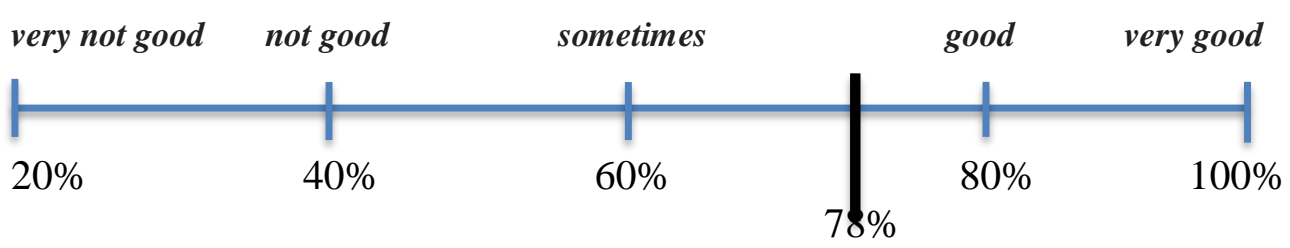

Figure 4 Line Continuum Respondents Response Against Immigration Gate Service 
E. Convenience Analysis on Boarding Lounge

Based on Figure 5 it can be seen that overall perception about boarding lounge comfort is $76.6 \%$. This shows that most respondents state that the convenience of boarding lounge is already comfortable.

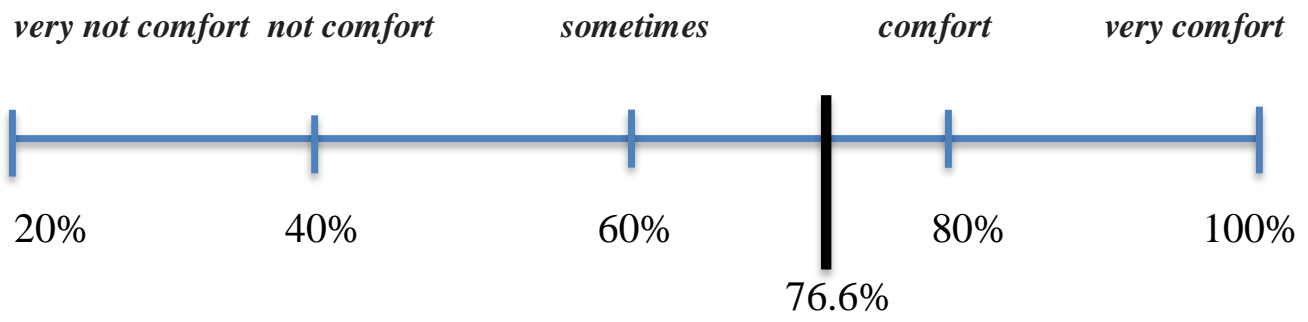

Figure 5 Continuum Line Response Response Against Boarding Lounge Convenience Overview of Service Quality as a whole

\begin{tabular}{|c|c|}
\hline Services & $\begin{array}{c}\text { Average of Value } \\
(\%)\end{array}$ \\
\hline Boarding Signage & 70,9 \\
\hline Security Check Point & 79,1 \\
\hline Check-in Counter & 77,4 \\
\hline Immigration & 78 \\
\hline Boarding Lounge & 76,6 \\
\hline TOTAL & $\mathbf{3 8 2}$ \\
\hline TOTAL AVERAGE & $\begin{array}{c}\mathbf{7 6 , 4} \\
\text { (appropriate) }\end{array}$ \\
\hline
\end{tabular}

Responses of respondents to the overall service quality can be described on the continuum line below:

very inaccurate inaccurate

sometimes

accurate

very accurate

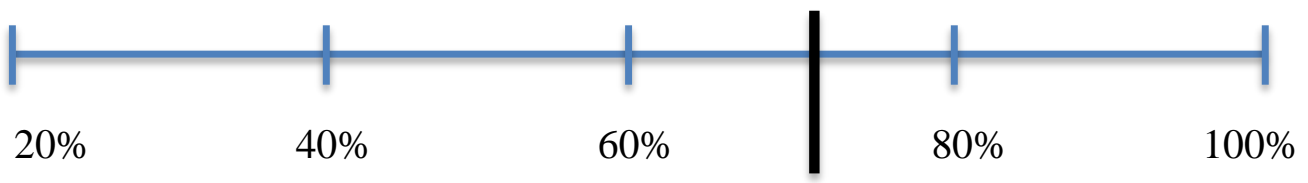

$76.4 \%$

Based on the above table as a whole the Service Quality at Terminal 3 International Terminal Ultimate and according to the responses of respondents are in the category appropriate or satisfied. This can be seen from the percentage of the total average of the overall service. Quality of service obtained is equal to $76.4 \%$. 


\section{Conclusion}

Based on the result of the research that has been done in finding out the influence of passenger satisfaction to the terminal 3 ultimate soekarno-hatta international airport, then it is obtained conclusion. Based on the analysis of passenger satisfaction of Terminal 3 Ultimate, it is included in satisfied or good category. This means that the services at Terminal 3 Ultimate get positive values and impressions from passengers which must always be improved.

The suggestions that writers can convey are:

1. Overall, from the results of research on the perception of passengers Terminal 3 Ultimate Soekarno-Hatta International Airport is good in its service. To increase passenger satisfaction Terminal 3 Ultimate SoekarnoHatta International Airport, it needs to improve the quality of service in providing satisfaction to attract foreign tourists and improve the image of the State of Indonesia.

2. More technical suggestions are as follows:

a. Increase the number of employees on boarding

b. Fixed lay outs for more comfort, increased visitor and passenger order, and improved tidiness and cleanliness

c. Enhance the security of Terminal 3 Ultimate Soekarno-Hatta International Airport

d. Utilizing, upgrading, managing and maintaining facilities (facilities and infrastructure), such as wifi, toilets, cinema $\&$ game center must always be done

e. Increase seat capacity and parking information

f. Expand the size of the terminal facility so that the build-up of overload doesn't occur.

\section{References}

Agushinta, L., \& Wiratama, A. (n.d.). PELAYANAN FASILITAS TERMINAL 
BAGI, 267-275.

Kalakou, S., \& Moura, F. (2015). Modelling passengers' activity choice in airport terminal before the security checkpoint: The case of portela airport in Lisbon. In Transportation Research Procedia (Vol. 10, pp. 881-890). https://doi.org/10.1016/j.trpro.2015.09.041

Keputusan Menteri Perhubungan No. 11 tahun 2010 Tentang Tatanan Bandara Internasional Soekarno-Hatta.

Manataki, I. E., \& Zografos, K. G. (2009). A generic system dynamics based tool for airport terminal performance analysis. Transportation Research Part C: Emerging Technologies, 17(4), 428-443. https://doi.org/10.1016/j.trc.2009.02.001

Nurtjahjo, Rianto; SE, M. (2016). Dwelling Time, 220-228. Retrieved from http://sbm.binus.ac.id/2016/04/14/dwelling-time/

Pengguna, K., Transportasi, J., Loyalitas, U. M., Saribanon, E., Tinggi, S., Trisakti, M. T., ... Trisakti, T. (2016). Kepuasan Pengguna Jasa Transportasi Untuk Meningkatkan Loyalitas the Satisfaction of Transportation'S Customers To Enchance Loyalty. Jurnal Manajemen Transportasi \& Logistik, 3(3), 317326.

Pradana, A. N., \& Ahyudanari, E. (2017). Evaluasi Ketersediaan Gate Di Terminal 3 Ultimate Bandar Udara Internasional Soekarno- Hatta, 6(1), 3-7.

Sastranegara, B. H. (n.d.). Jasa Pelayanan Bandara Halim Perdana Kusuma dan, $3(1), 1-11$.

Suhaedi, E., \& Ariyanto, R. (n.d.). KEBUTUHAN FREKUENSI PENERBANGAN RUTE JAKARTA - JOGYAKARTA - JAKARTA PT INDONESIA AIR ASIA, 305-326.

Sugiyono. (2011). Metode Penelitian Pendidikan. Bandung: Alfabeta

http://www.angkasapura2.co.id/en/tentang/sejarah 